\title{
ADMINISTRAÇÃO DE PESSOAL
}

\section{Desvio de Função \\ Venero Caetano da Fonseca}

$\mathrm{D}$

E um modo geral, os candidatos ao serviço público são atraidos pelos vencimentos dos respectivos cargos, dentro de uma faixa de motivação subjetiva.

Assim é que, relativamente aos estudantes - para os quais o emprêgo público é um meio e não um fim - os vencimentos, embora, reduzidos representam sempre um justificado interêsse.

Mas, infelizmente, os nossos niveis de vencimentos solapados pela inflação, não constituem, objetivamente, atração suficiente, para movimentar um grande número de pretendentes, que tencionam fazer carreira, erigindo o serviço público em meta, a ser atingida pela progressão funcional. do curso.

Os universitários, comumente, pedem exoneração ao término

Muitos servidores exercem também atividades privadas, suplementando os vencimentos com salários de emprêsas particulares, transformando o trabalho da repartição em tarefa meramente acessória.

Por outro lado, as funç̃oes gratificadas, que seriam um estímulo ao esfôrço de profissionalização, representam, via de regra, $11 \mathrm{~m}$ acréscimo de vencimentos pequenos, insuficiente para despertar maiores interêsses.

Há, enfim, um grande número de funcionários que ingressam no serviço público, casualmente, sem um mínimo de vocação. Fazem concurso para artífice, por exemplo, como teriam feito para marinheiro ou datilógrafo.

Os vencimentos anunciados naquele momento de sua vida significavam-lhes um proveito imediato.

Completamente sem qualquer tendência para o exercício do cargo, vão êsses funcionários, gradativamente, sendo experimentados, por conveniência da administração, em diversas atribuições, até que se ajustem, com um rendimento útil, em tarefas realmente consentâneas com as suas autênticas possibilidades e vocações.

Daí ser comum em muitas repartições a falta de coincidência formal dos encargos com os respectivos executantes, ocupantes 
de cargos cujas denominações diferem inteiramente daquelas atividades que a nomenclatura dos cargos poderia sugerir.

Atendente funcionando como datilógrafo; escriturário, como atendente; eletricista trabalhando como motorista; laboratorista, como oficial de administração; artífice, como cabineiro de elevador, etc. etc.

A ocorrência de trabalhos diversos daqueles pertinentes aos cargos é ainda maior no que concerne a funcionários interinos, por falta de verificação de aptidões através das provas de um concurso.

São êsses e aquêles servidores inadaptados às tarefas que seriam próprias de seus cargos e, por isso, exercem outras, relacionadas com outros cargos.

Para corrigir êsses desvios de funções, foi criado, pela Lei $\mathrm{n}^{\circ} 3.780$ de 12-7-960, o instituto da readaptação, regulamentado pelo Decreto $n^{\circ} 49.370$ de 29-11-960.

Na forma do art. 43 da lei citada,

"será readaptado o funcionário que venha exercendo, ininterruptamente, e por prazo superior a dois (2) anos, atribuiçốes diversas das pertinentes à classe em que fôr enquadrado, ou haja exercido estas atribuições, até 21 de agôsto de 1959, por mais de 5 (cinco) anos ininterruptos".

Paralelamente a essa solução, dispôs o art. 47 da referida lei:

"Art. 47. Após a implantação do nôvo sistema de de classificação, respeitadas as exceções previstas nesta lei, será responsabilizado o Chefe de Serviço, sob pena de demissão, ou destituição de função, que conferir a a qualquer servidor atribuição diversa da pertinente à classe a que pertence. Em caso algum poderá tal fato acarretar a reclassificação do funcionário ou sua readaptação; determinará apenas a correção da irregularidade, mediante retôrno do funcionário às atribuições do seu cargo".

Foi, sem dúvida, uma proibição radical. Visando a atenuarThe os efeitos, através de uma sábia interpretação da Comissão de Classificação de Cargos, decidiu-se que

"o assunto se apresenta, de fato, complexo, e sòmente admitirá solução após a definição de atribuições das séries de classes ou classes dos grupos ocupacionais respectivos". (D. O. de 14-3-961). 
Essa inteligente e oportuna correção interpretativa foi um importante passo a diminuir o impacto que causaria o aludido art. 47, se aplicado fôsse, sùbitamente, sem os preparativos necessários.

Outras medidas, no mesmo sentido, já estarão, por certo, sendo cogitadas, à vista dos problemas gerados pela proibição de "conferir a qualquer servidor atribuição diversa da pertinente à classe a que pertence".

$E^{\prime}$ verdade que o Estatuto dos Funcionários - Lei $n^{\circ} 1.711$ de 28-10-52, - já dizia, em seu art. $7^{\circ}, \S 3^{\circ}$ que

“ $E$ ' vedado atribuir-se ao funcionário encargos ou serviços diferentes dos que os próprios de sua carreira ou cargo, e como tais sejam definidos em Leis ou Regulamentos".

$\mathrm{E}^{\prime}$ verdade também, que, antes como agora, ainda não ocorreu a prevista (art. $7^{\circ}, \S 1^{\circ}$ do E. F. e art. 6\% da Lei 3.780 de 12-7-960) especificação, em regulamento, das atribuições, responsabilidades e demais caracteristicas pertinentes a cada classe.

Ainda assim, já está pôsto o problema, pois o anexo I da Lei $n^{\circ} 3.780$ de 1960 sintetiza as caracteristicas das classes. E, também, atualmente, já está - anteriormente não estava - cominada, expressa e objetivamente, no art. 47 da Lei 3.780 de 1960, a penalidade correspondente à infração.

Então, publicado o enquadramento definitivo, terá a Repar tição que observar a proibição do art. 47 ?

Rigorosamente, parece-nos que não, visto como isso só será possivel depois que forem especificadas em regulamento as atribuições, responsabilidades e demais caracteristicas pertinentes a cada classe (art. 6ㅇ da Lei $n^{\circ} 3.780$ de 1960).

E' essa regulamentação por certo que redescobrirá, no malsinado art. 47, ângulos menos perigosos e menos inconvenientes à administração do que aquêles friamente ostentados pela lei.

Enquanto não fôr alterado o art. 47, também muito poderá fazer para reformular os seus efeitos a Divisão de Classificação de Cargos, com podêres, inclusive, para preparar instruções e atos necessários à perfeita execução da Lei no 3.780-60 (art. 40, item VI)

Aliás, o art. 23 do Decreto n 49.370 de 29-11-960 - que dispôs sôbre a readaptação — já, também sàbiamente, adiou aplicação do art. 47 , quando diz:

"Após a implantação do nôvo sistema de classificação, constante da Lei n? 3.780, de 12-7-960, e concluida a readaptação de que trata êste decreto (o grifo 
é nosso), será responsabilizado o Chefe do Serviço, sob pena de demissão ou destituição, que conferir a qualquer servidor atribuição diversa da pertinente à classe a que pertence".

\section{êste \\ A readaptação só poderá corrigir o desvio da função, se}

“dura, pelo menos, há mais de dois anos ininterruptos, imediatamente antes de 12 de julho de 1960, ou mais de cinco anos ininterruptos, imediatamente antes de 21 de agôsto de 1959" (art. 7\%, II, Decreto n 49.370 de 1960).

Os desvios de funções, fora daquela duração ou que, também no interêsse do serviço, continuarem - e continuam - ocorrendo, só poderão ser retificados por uma nova lei.

Foi o que aconteceu, recentemente, com os operadores postais do DCT, autorizados a ingressar na classe inicial da Sériø de Classes a cujas tarefas típicas corresponder o trabalho que êsses funcionários venham executando.

E' a própria Lei n' 4.203, de 7-3-963, publicada no Diário Oficial de 8-2-63, reconhecendo que continuam os inevitáveis desvios de funções, quando dispõe no parágrafo único do art. $3{ }^{\circ}$.

"Parágrafo único. Se houver funcionários beneficiados pela execução contida neste artigo que, antes ou depois do advento da Lei $n^{\circ} 3.780$, de 1960, tenham sido deslocados por absoluta necessidade dos serviços, para o exercício de atribuições diversas das pertinentes à Série de Classes de Operador Postal, no caso de o deslocamento contar, nesta data, pelo menos, dois anos ininterruptos, a êle ficará assegurado o direito de optar pelo ingresso na classe inicial da Série de Classes a cujas tarefas típicas corresponder o trabalho que êsses funcionários venham executando.

Estudos mais acurados, orientarão as modificações que a realidade exige, relativamente aos artis. 43 e 47 da Lei $n^{\circ} 3.780$ de 1960.

O registro dessas observações é apenas uma constatação do descompasso da lei com a vivência do serviço público.

Todavia, lembramos que a fatalidade do desvio de função, imposta pelas necessidades do serviço, só tenderá a desaparecer mediante, inclusive, a reformulação do recrutamento e seleção de pessoal, baseada em apurações vocacionais. 